\title{
The Changing Image of Physician in Taiwan
}

\author{
Y. M. Chang ${ }^{1}$, Henry Bair ${ }^{2} \&$ Jar-Yuan Pai ${ }^{3}$ \\ ${ }^{1}$ Center for Liberal Arts, Taipei Medical University, Taiwan \\ ${ }^{2}$ Morrison Academy, Taiwan \\ ${ }^{3}$ Department of Health System Management, Chung Shan Medical University, Taiwan \\ Correspondence: Jar-Yuan Pai, Department of Health System Management, Chung Shan Medical University, No. \\ 110, Sec.1, Jianguo N. Rd., Taichung City, Taiwan. Tel: 886-4-2205-3362. E-mail: jpai00@gmail.com
}

\author{
Received: January 21, 2013 Accepted: February 7, 2013 Online Published: March 28, 2013 \\ doi:10.5539/ass.v9n4p32 \\ URL: http://dx.doi.org/10.5539/ass.v9n4p32
}

\begin{abstract}
Traditionally, physicians in Taiwan have held a positive image and have possessed high socio-economic standing. However, public attitudes to doctors have changed in recent times. The professional image of physicians has been overshadowed by a series of scandals of malpractice and fraud. The doctor's white coat, which symbolized humanism and professionalism, has seemingly been tainted; as have the well-respected life-saving professional image of physicians. The aim of this study was to understand the change of the professional image of physicians over time in Taiwan and to see whether it has been affected by the implementation of the National Health Insurance (NHI) program. Competence, autonomy, dominance, authority, altruism, de-professionalization, corporatization and commercialization were factors considered in the analysis of the professional image of physicians. Through the examination of newspapers and academic journals, content analysis technique was then deployed to assess the change in physicians' professional image over time, as well as before and after the inception of the NHI program. Altruism, authority and competence, which form the traditional definition for medical professionalism, are identified as the top four factors in the Taiwan Medical Journal. However, in the newspapers, the numbers for these factors have decreased except those for corporatization; in the Taiwan Medical Journal, the numbers for competence, dominance and authority have dropped; and numbers for autonomy, altruism, corporatization and commercialization have increased, with those for de-professionalization remaining the same. Although the socioeconomic status of physicians is still lofty after the social changes, the income of physicians have dropped in Taiwan.
\end{abstract}

Keywords: physician, professional image, transition, national health insurance

\section{Introduction}

The media is flooded with negative images of physicians, such as the embezzling of National Health Insurance fees, sexual harassment, medical mistakes, and so on. Leaders in medicine denounced these wrongdoings as examples of "the deterioration in medical ethics" and "a destructive force that has shattered the reputation of physicians". Physicians are the representation of professionals. On the whole, physicians strengthen their professional image through autonomy and monopoly. Yet, Light \& Levine believe that the medical profession will fade away under the question of "de-professionalization", "pro-lateralization" and "corporatization" (Light \& Levine 1988). As medical intuitions grow, corporatization of hospital management has become inevitable (Ting, 1999).

\section{Research Frame}

Image is a combination of impression, themes, opinions and attitudes, and is equivalent to stereotype and generalization (Merrill, 1962). The professional image of physicians originates from the oath of Hippocrates, which is constantly related to altruism, authority and professionalization (Yothasamut, Tantivess \& Teerawattananon, 2009). Talcott Parsons discussed structural-functionalism from a modern medical development point of view. He believes that the professional medical image includes altruism and collectivity; and that the base for trust lies in medical institutionalized norms (Parsons, 1951). However, Cheng believes that Parsons' structural-functionalism implies a tendency for conservative power where physician-patient relationship emerges from the angle of maintaining the social system (Cheng, 2002). Rowland, Coe, Burchard, and Pricolo carried out a study regarding the ideal image of physicians (Rowland et al., 2005). They found that the complicated, worthy, 
and specialized profession physicians possess enabled the dominant and competent roles they play. In addition, Freidson defined the profession of physicians as an occupation that has achieved autonomy or self-direction based on the dual characteristics of its specialty and promise (Freidson, 1970a; Freidson, 1970b). He emphasized the importance of exclusive knowledge not only in medical professionalization but also in offering medical service and medical organizations (Freidson, 1975; Freidson, 1986; Freidson, 1970b). He believes the professional dominance status in the medical system will not be changed, thus creating a professional medical culture (Freidson, 1985).

However, Freidson's professionalism was criticized during the 1960s and 1970s as medical professionalism was deemed as a diversion to the fact that physicians' interests exceed the interest of the society. Due to the development of global computerization and education, the rapid flow of information has made modern people more aware of the medical and health issues. De-professionalism became a potential trend (Haug, 1973; Haug, 1976; Haug \& Lavin, 1979; Haug \& Lavin, 1981; Light \& Levine, 1988). On the other hand, since the growth of medical institutes continues, physicians also face the stress of corporatization and commercialization (Hafferty, 1988; Light \& Levine, 1988). Pro-lateralization focuses on professionalism, capitalism, and the relationship between classes. It proposes development of technology via capital accumulation, and compelling professionalism to submit to and depend on capitalists' provision. The influence of the capitalism encouraged the effective operation and management of hospitals. Physicians were hired by the commercial organizations whose responsibilities focused on the overall benefits rather than personal benefits of patients. According to Huang and Lavin (Haug \& Lavin, 1979), the emergence of large corporations has changed the authority of traditional physician-patient relationship. Consumerism focuses on the patient's purchase rights and physician's sale obligation. The relatively negative image of de-professionalization, corporatization and commercialization did affect people's attitudes towards physicians to some extent.

In brief, the medical profession today has changed as large hospital organizations, government implemented medical insurance, and consumerism trends have taken lead in physician-patient relationship. Most physicians are aware of the change in their social status and the corrosion of their profession. Communication and trust between physician-patient relationships are strained, and physicians are no longer omnipotent characters.

According to Stoeckle (Stoeckle, 1988), there are three factors that influence physician behavior, which also influences physician images today:

1) Competitive organizations lead to a more bureaucratic environment where physicians become employers and physician-patient relationship reflects the benefit of the organization not the patient.

2) Physicians today rely mostly on medical technology and are becoming more occupationally specialized.

3) The standardization of physician's work by supervision of information system etc.

Based on the knowledge of the previous literature, the research frame of the current study was set as the examination of the relatively positive image, i.e. competence, autonomy, dominance, authority, altruism and relatively negative image de-professionalization, corporatization and commercialization of the physicians during a specific time frame.

Content analysis was implemented to analyze and describe the data systematically. Lombard et al. pointed out that content analysis was the most adaptable method as far as mass communication was concerned (Lombard, Snyder-Duch \& Bracken, 2002). Berelson also mentioned that content analysis was an objective, systematic and descriptive method for communication research (Berelson, 1952).

The hypotheses of the study were: 1 . the professional image of physicians in Taiwan has changed through time. 2. The professional image of physicians in Taiwan has changed as a result of the inception of the NHI program.

\section{Method and Reliability}

This research identifies eight essential factors of physicians' professional image, including competence, autonomy, dominance, authority, altruism, de-professionalization, corporatization, and commercialization. Content analysis technique was deployed to assess any change in physicians' professional image over time. Two types of media were examined, including newspapers and medical journals. Time frames of the publications embraced the inception of the NHI program, through examination of two types of media-newspapers and medical journals:

\subsection{Newspaper}

First, newspapers reflected the attitudes of the general public and were chosen as the main content of this study. Concerning the coverage rate and publication date of the newspaper media, United Daily News, China Times, 
Liberty Times and Apple Daily were chosen for data collection. Starting from 2009, 50 samples were selected every 5 years. Articles with more than 300 words, on the front page, and containing keywords of hospitals, medicals, physicians, et cetera, with correspondent definition were selected. A sample of 1,372 reported stories between 1954 and 2009 was selected after invalid samples were eliminated (see Table 1).

Table 1. Sample newspaper articles between 1954 and 2009

\begin{tabular}{llllll}
\hline Sampling year & $\begin{array}{l}\text { United Daily } \\
\text { News }\end{array}$ & China Times & Liberty Times & Apple Daily & Total \\
\hline 1954 & 50 & 50 & 0 & 0 & 100 \\
1959 & 50 & 50 & 0 & 0 & 100 \\
1964 & 50 & 50 & 0 & 0 & 100 \\
1969 & 50 & 50 & 0 & 0 & 100 \\
1974 & 50 & 50 & 0 & 0 & 100 \\
1979 & 50 & 50 & 0 & 0 & 100 \\
1984 & 50 & 50 & 0 & 0 & 100 \\
1989 & 50 & 50 & 50 & 0 & 150 \\
1994 & 50 & 50 & 50 & 0 & 150 \\
1999 & 50 & 50 & 50 & 0 & 150 \\
2004 & 50 & 50 & 50 & 50 & 200 \\
2009 & 50 & 50 & 50 & 50 & 1550 \\
Total & 600 & 600 & 250 & 100 & \\
\hline
\end{tabular}

Mean scores of the positive image of physicians on newspapers

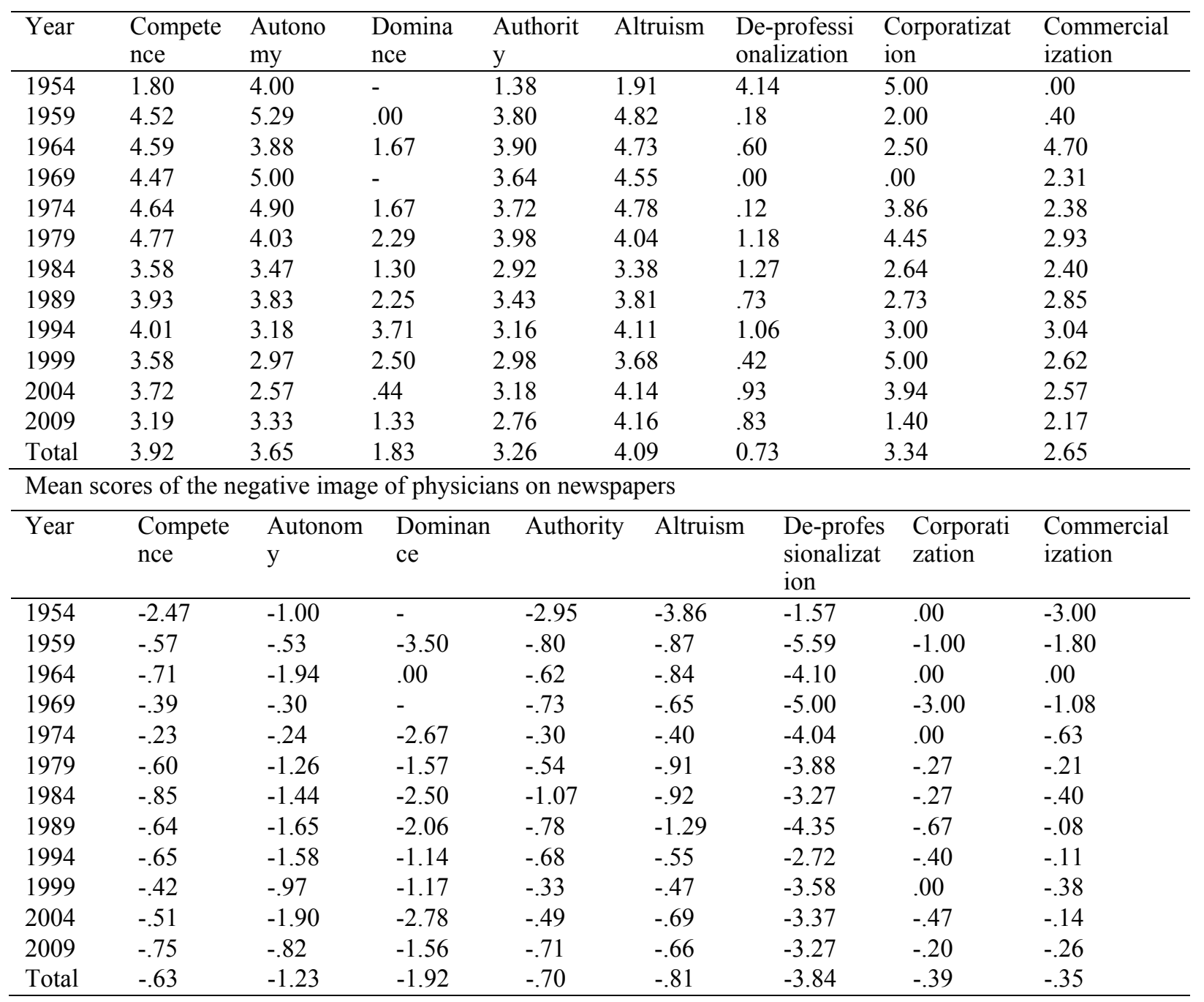


Content analysis was enforced to analyze the data collected. The procedures of the content analysis are as followed: research question and hypotheses, definition of the sample, sampling, categorization, setting units, systematizing for quantitative data, prediction, coding, analyzing data, conclusion and explanation.

Before coding, the categorization of the coding form was established. Data coding were executed by 5 postgraduate students. A pre-test was carried out on $5 \%$ of the original sample to ensure the internal reliability was higher than 0.8 .

In addition to reporting descriptive statistics of frequency, topics, sources and length of the reports, a score between -10 to +10 is also given to each report based on its ratings on the eight factors of professional image.

\subsection{Taiwan Medical Journal}

The Taiwan Medical Journal, published by the Taiwan Medical Association, was chosen to reflect physicians' perspectives over time. The Taiwan Medical Journal was founded in 1958, and is still published today. A total of 52 editorials or special reports published between 1958 and 2009 were selected (see Table 2).

Table 2. Number of sample articles from the Taiwan Medical Journal

\begin{tabular}{ll}
\hline Sampling year & Articles \\
\hline 1958 & 11 \\
1959 & 26 \\
1964 & 135 \\
1969 & 64 \\
1974 & 167 \\
1979 & 103 \\
1984 & 103 \\
1989 & 65 \\
1994 & 63 \\
1999 & 57 \\
2004 & 55 \\
2009 & 9 \\
Total & 858 \\
\hline
\end{tabular}

\section{Results}

Altruism, autonomy, authority, and competence are four of the most commonly identified factors of professional image among articles in the Taiwan Medical Journal. These four factors are also the key elements in the traditional definition of medical professionalism, which is typically recognized and associated with physicians' professional image by both the public and physicians. In contrast, competence, authority, and altruism became less frequently mentioned in the newspapers.

While commercialization of medical institutes was not widely discussed in the medical industry, it was a popular topic among the general public. This phenomenon may indicate that newspapers generally promoted more health related educational information than information on commercialized image, with $60 \sim 90 \%$ of the articles focusing on competence, altruism and authority (Taiwan Medical Journal). Another reason may be that the strict medical laws and the media's effective screening blocked the information of commercialization from medical press conferences. The low appearance of commercialization topics conforms to Lupton and Mclean's research where medical commercialization reports appear less than 1\% (Lupton \& McLean, 1998).

The traditional image of "altruism" appeared frequently in the media and was largely praised by the newspapers. After 1959, negative scores between -1 and 0 appeared as the public becomes aware of the physicians' image in terms of altruism. However, physicians themselves were dubious of their professional image in varying degrees.

Since the inception of the NHI, the physicians' professional image has drastically transformed (Tarn et al., 2008). With respect to the frequency of discussion of the eight factors in the newspaper, with the exception of 
commercialization, which experienced a slight increase from $12.6 \%$ to $13.5 \%$, the numbers of reports on other factors - competence, autonomy, dominance, authority, altruism, de-professionalization and corporatization all declined, especially for altruism and competence, which dropped $12.3 \%$ and $8.4 \%$, respectively. This suggests a significant impact of the NHI on the professional image of physicians.

On the other hand, the numbers of articles on competence, dominance and authority in the Taiwan Medical Journal have reduced after the implementation of the NHI, with competence decreasing the most. On the contrary, the numbers for autonomy, altruism, corporatization and commercialization have increased while that of de-professionalization remained the same.

Though little attention was paid to the de-professionalization of physicians, when compared with "authority", they are still well-respected by the public. The physicians' professional status is not lowered by the popularization of knowledge. Yet, it is interesting to note that they have more sense of crisis in this respect. Since the Physician's Act in 1969, physician's awareness of de-professionalization has increased. The appearance of de-professionalization occurred more frequently while the sense of authority dropped sharply;; this may be caused by the increase of medical disputes during that period.

Furthermore, "corporatization" is closely linked to whichever institution the physician belongs to. According to the Taiwan Medical Journal, the heated discussion in 1969 may be related to Mackay Memorial Hospital's private physician fee (PPF).

From the opposing concepts of Parsons and Freidson, the eight professional images can be divided into two aspects: 1) from the patients' aspect and 2) from the physicians' aspect. Patients need a physician that not only sees from their point of view, but also possesses sufficient competence and authority, such as Parson's altruism, competence and authority factors. In Freidson's point of view, physicians distance themselves from the public with their professional image, but are closer to factors concerning their own interests such as autonomy and control. This is reflected in the newspapers representing the common public and the Taiwan Medical Journal representing physicians.

It has been suggested that the NHI has a critical effect on physicians' professional autonomy, altruistic behavior, and commercialization, as well as the market concentration of medical institutions. Consequently, the numbers of related articles on these four factors increased substantially in the medical journals.

\section{Conclusion}

For the general public, physicians are still very much competent, authoritative, life-saving professionals and the image has not shifted too much away from paternalism. However, the attitudes are changing as a result of the growing commercialization of health care, which raises concerns over the ethical implications of profit-seeking and self-interest driven medical practice. The inception of NHI is deemed as a revolutionary policy that changed the environment of the medical market. However, its discussion frequency in the newspapers and on Taiwan Medical Journal differs. In the newspapers, the discussion frequency of the eight factors had all dropped, except for the frequency for commercialization, which rose slightly. Whereas in the Taiwan Medical Journal, the appearance of competence, dominance and authority dropped; autonomy, altruism, corporatization and commercialization rose; and de-professionalization remained the same. The NHI program may have also catalyzed the transformation of physicians' professional image through its effect on the overall market. Yet, it should be noted that neither newspapers nor tabloids have deliberately vilified the medical industry. Medical educators and policy-makers must carefully consider these changes and their implications in their future planning of the health systems.

Research on domestic physician's professional image has long been established in surveys and in-depth interviews. This method of research may cause a lack of objectivity on the analysis of past records.

Old media vanishes from the market as new media is introduced into the market. As the basis of comparison shifts, the difficulty in choosing appropriate samples increases. In the future, the method with which to adjust the medium gap between old and new media, such as between newspapers and online media, will need further consideration.

\section{References}

Berelson, B. (1952). Content analysis in communication research. New York: Free Press.

Cheng, L. F. (2002) Knowledge and Power in Professional-User Relationship. Taiwanese Journal of Sociology, 3, 11-71.

Freidson, E. (1970a). Professional Dominance: The Social Structure of Medical Care. New York: Atherton Press. 
Freidson, E. (1970b). Professional of Medicine: A Study of the Sociology of Applied Knowledge. New York: Dodd-Mead.

Freidson, E. (1975). Doctoring Together: A Study of Professional Social Control. Chicago: University of Chicago Press.

Freidson, E. (1985). The reorganization of the medical profession. Medical Care Review, 42, 11-35. http://dx.doi.org/10.1177/107755878504200103

Freidson, E. (1986). Professional Powers: A Study of the Institutionalization of Formal Knowledge. Chicago University of Chicago Press.

Hafferty, F. W. (1988). Theories at the Crossroads: A Discussion of Evolving Views on Medicine as a Profession. Milbank Q, 66, 202-225. http://dx.doi.org/10.2307/3349923

Haug, M. (1973). Deprofessionalization: An Alternate Hypothesis for the Future. Sociological Review Monograph, 20, 195-211.

Haug, M. (1976). The Erosion of Professional Authority: A Cross-cultural Inquiry in the Case of the Physician. Milbank Memorial Fund Quarterly, 54, 83-106. http://dx.doi.org/10.2307/3349670

Haug, M., \& Lavin, B. (1979). Public Challenge of Physician Authority. Medical Care, 17, 844-858. http://dx.doi.org/10.1097/00005650-197908000-00007

Haug, M., \& Lavin, B. (1981). Practitioner or Patient-Who's in Charge? Journal of Health and Social Behavior, 22, 212-229. http://dx.doi.org/10.2307/2136517

Light, D., \& Levine, S. (1988). The Changing Character of the Medical Profession: A Theoretical Overview. The Milbank Quarterly, 66, 10-32. http://dx.doi.org/10.2307/3349912

Lombard, M., Snyder-Duch, J., \& Bracken, C. C. (2002). Content analysis in mass communication: Assessment and reporting of intercoder reliability. Human Communication Research, 28, 587-604. http://dx.doi.org/10.1111/j.1468-2958.2002.tb00826.x

Lupton, D., \& McLean, J. (1998). Representing Doctors: Discourses and Images in the Australian Press. Social Science \& Medicine, 46, 947-958. http://dx.doi.org/10.1016/S0277-9536(97)10013-2

Merrill, J. (1962). The Image of the United States in Ten Mexican Dailies. Journalism Quarterly, 39, 203-212. http://dx.doi.org/10.1177/107769906203900208

Parsons, T. (1951). The Social System. New York: Free Press.

Rowland, P. A., Coe, N., Burchard, K., \& Pricolo, V. (2005). Factors Affecting the Professional Image of Physicians. Current Surgery, 62, 214-219. http://dx.doi.org/10.1016/j.cursur.2004.08.008

Stoeckle, J. D. (1988). Reflections on Modern Doctoring. Milbank Q, 66, 76-91.

Tarn, Y. H., Hu, S., Kamae, I., Yang, B. M., Li, S. C., Tangcharoensathien, V., ... Bapna, J. S. (2008) Health-care systems and pharmacoeconomic research in Asia-Pacific region. Value in Health, 11, S137-155. http://dx.doi.org/10.1111/j.1524-4733.2008.00378.x

Ting, C. Y. (1999). How Do Physicians Regard Managerial Intervention in Hospitals? Chinese Journal of Public Health, 18, 152-166.

Yothasamut, J., Tantivess, S., \& Teerawattananon, Y. (2009). Using Economic Evaluation in Policy Decision-Making in Asian Countries: Mission Impossible or Mission Probable? Value in Health, 12, S26-30. http://dx.doi.org/10.1111/j.1524-4733.2009.00623.x 


\section{Appendixes}

Appendix A. Descriptive data

\begin{tabular}{|c|c|c|c|}
\hline Variables & & Frequencies & Percentage \\
\hline \multirow[t]{4}{*}{ Newspaper } & United Daily & 535 & $38.9 \%$ \\
\hline & China Times & 499 & $36.3 \%$ \\
\hline & Liberty Times & 243 & $17.7 \%$ \\
\hline & Apple Daily & 97 & $7.1 \%$ \\
\hline \multirow[t]{6}{*}{ Year } & $1951-1960$ & 89 & $6.5 \%$ \\
\hline & 1961-1970 & 172 & $12.5 \%$ \\
\hline & $1971-1980$ & 194 & $14.1 \%$ \\
\hline & 1981-1990 & 239 & $17.4 \%$ \\
\hline & $1991-2000$ & 291 & $21.2 \%$ \\
\hline & After 2001 & 389 & $28.3 \%$ \\
\hline \multirow[t]{4}{*}{ Word count } & $300-500$ & 359 & $262.2 \%$ \\
\hline & $501-1000$ & 808 & $58.9 \%$ \\
\hline & $1001-2000$ & 189 & $13.8 \%$ \\
\hline & Above 2000 & 16 & $1.2 \%$ \\
\hline \multirow[t]{2}{*}{ Personal photos } & $\mathrm{N}$ & 1310 & $95.4 \%$ \\
\hline & $\mathrm{Y}$ & 63 & $4.6 \%$ \\
\hline \multirow[t]{6}{*}{ Types of news } & Daily news & 1105 & $80.5 \%$ \\
\hline & Letters from readers & 116 & $8.4 \%$ \\
\hline & Features $\&$ analysis & 67 & $4.9 \%$ \\
\hline & Special reports & 60 & $4.4 \%$ \\
\hline & Editorials & 13 & $0.9 \%$ \\
\hline & Others & 12 & $0.9 \%$ \\
\hline \multirow[t]{13}{*}{ News sources I } & Physicians and professional groups & 1145 & $83.3 \%$ \\
\hline & Staff from the competent authority & 69 & $5.0 \%$ \\
\hline & Unknown & 66 & $4.8 \%$ \\
\hline & Governmental staff & 59 & $4.3 \%$ \\
\hline & Reporters or editors & 42 & $3.1 \%$ \\
\hline & Patients or consumer groups & 40 & $2.90 \%$ \\
\hline & Scholars or academic groups & 15 & $1.1 \%$ \\
\hline & Friends of the patients & 15 & $1.1 \%$ \\
\hline & Medical personnel & 14 & $1.0 \%$ \\
\hline & Others & 14 & $1.0 \%$ \\
\hline & Common citizens & 9 & $0.7 \%$ \\
\hline & Commercial groups & 6 & $0.4 \%$ \\
\hline & Medical or health journals & 1 & $0.1 \%$ \\
\hline \multirow[t]{7}{*}{ News sources II } & $\begin{array}{llc}\text { Academic } & \text { background } & \text { in } \\
\text { management } & & \end{array}$ & --- & --- \\
\hline & Hospital chairman/vice-chairman & 98 & $7.1 \%$ \\
\hline & Professors from medical school & 91 & $6.6 \%$ \\
\hline & Others & 5 & $0.4 \%$ \\
\hline & Staff from the competent authority & 4 & $0.3 \%$ \\
\hline & Academic background in law & 2 & $0.1 \%$ \\
\hline & $\begin{array}{l}\text { Representatives from the patient } \\
\text { groups }\end{array}$ & 1 & $0.1 \%$ \\
\hline
\end{tabular}




\begin{tabular}{|c|c|c|c|}
\hline \multirow[t]{19}{*}{ News topics } & $\begin{array}{l}\text { Health issues about diseases or } \\
\text { medicine }\end{array}$ & 647 & $47.1 \%$ \\
\hline & Medical development & 113 & $8.2 \%$ \\
\hline & $\begin{array}{l}\text { Physicians involved in scandals or } \\
\text { illegal events }\end{array}$ & 67 & $4.9 \%$ \\
\hline & Hospital management & 58 & $4.2 \%$ \\
\hline & Others & 54 & $3.9 \%$ \\
\hline & $\begin{array}{l}\text { Physicians participating in social } \\
\text { activities }\end{array}$ & 52 & $3.8 \%$ \\
\hline & $\begin{array}{l}\text { Introduction of medical technology, } \\
\text { equipment or medicine }\end{array}$ & 45 & $3.3 \%$ \\
\hline & physician introduction & 44 & $3.2 \%$ \\
\hline & Medical disputes & 41 & $3.0 \%$ \\
\hline & Medical policies & 43 & $3.1 \%$ \\
\hline & Health insurance & 37 & $2.7 \%$ \\
\hline & Epidemic situation & 35 & $2.5 \%$ \\
\hline & Medical education or training & 34 & $2.5 \%$ \\
\hline & Traditional Chinese medicine & 29 & $2.0 \%$ \\
\hline & Ethical issues & 22 & $1.6 \%$ \\
\hline & Working environment of physicians & 18 & $1.3 \%$ \\
\hline & $\begin{array}{l}\text { Medical resources for remote districts } \\
\text { or vulnerable groups }\end{array}$ & 18 & $1.3 \%$ \\
\hline & Consumers issues & 14 & $1.0 \%$ \\
\hline & Marketing activities & 10 & $0.7 \%$ \\
\hline \multirow[t]{8}{*}{ Image } & Competence & 1028 & $74.8 \%$ \\
\hline & Autonomy & 386 & $28.1 \%$ \\
\hline & Dominance & 72 & $5.2 \%$ \\
\hline & Authority & 728 & $53.0 \%$ \\
\hline & Altruism & 904 & $65.8 \%$ \\
\hline & De-professionalization & 285 & $20.7 \%$ \\
\hline & Corporatization & 82 & $6.0 \%$ \\
\hline & Commercialization & 178 & $13.0 \%$ \\
\hline \multirow[t]{4}{*}{ Directions } & Negative & 162 & $11.8 \%$ \\
\hline & Neutral & 840 & $61.2 \%$ \\
\hline & Positive & 368 & $26.8 \%$ \\
\hline & Unknown & 2 & $0.1 \%$ \\
\hline
\end{tabular}

Appendix B. The coding form for data collected from newspapers

I Basic information of the news
a. Reference number: (ex: 0000001)
b. Staff:
c. Newspaper name: $\square$ 1. Apple Daily $\square$ 2. China Times $\square$ 3. Liberty Times $\square$ 4. United Daily News
d. Date: (Year) (Month) (Date)
e. Edition number \& name: No. _ Name
f. Word count: $\square 1.300 \sim 500 \square 2.501 \sim 1,000 \square 3.1,001 \sim 2,000 \square 4$. Above 2,000
g. Physicians' photos on the paper? $\square 0$. No $\square 1$.Yes 


\section{Types of news}

$\square$ 1.Daily news $\square$ 2.Special reports $\square$ 3.Features \& analysis $\square$ 4.Editorials $\square$ 5.Letters from readers $\square$ 6.Others

III News sources

a. The sources mentioned in the news?

$\square$ 0.Unknown $\square$ 1.Physicians and professional groups $\square$ 2.Medical personnel

$\square$ 3.Staff from the competent authority $\square$ 4.Governmental staff

$\square$ 5.Scholars or academic groups $\square$ 6.Patients or consumer groups

$\square$ 7.Friends of the patients $\square$ 8.Reporters or editors $\square$ 9. Medical or health journals

$\square$ 10.Commercial groups $\square$ 11.Common citizens $\square$ 12. Others

b. If the news sources were from physicians and professional groups, please identify the following background of the sources.

$\square$ 1.Professors from medical school $\square$ 2. Academic background in law $\square$ 3.Academic background in management

$\square$ 4.Hospital chairman/vice-chairman $\square$ 5. Staff from the competent authority

$\square$ 6.Representatives from the patient groups $\square$ 7.Others

IV News topics

$\square$ 1.Medical disputes $\square$ 2.Health issues about diseases or medicine $\square$ 3.Epidemic situation $\square$ 4.Working environment of physicians $\square$ 5.Hospital management $\square$ 6.Medical education or training $\square$ 7.Medical development $\square$ 8.Introduction of medical technology, equipment or medicine $\square$ 9.Health insurance $\square$ 10.Medical policies $\square$ 11.Ethical issues

$\square$ 12.Marketing activities $\square$ 13.Consumers issues $\square$ 14.physician introduction

$\square$ 15.Medical resources for remote districts or vulnerable groups $\square$ 16. Physicians involved in scandals or illegal events $\square$ 17.Traditional Chinese medicine $\square$ 18.Physicians participating in social activities $\square 19$. Others

V Elements of physicians' image

1. Competence

$\square$ None $(0$ point $) \square$ Yes, positive point $(0 \sim 10)$; negative $\operatorname{point}(0 \sim 10)$

2. Autonomy

$\square$ None( 0 point $) \square$ Yes, positive point $(0 \sim 10)$; negative $\operatorname{point}(0 \sim 10)$

3. Dominance

$\square$ None $(0$ point $) \square$ Yes, positive point $(0 \sim 10)$; negative $\operatorname{point}(0 \sim 10)$

4. Authority

$\square$ None $(0$ point $) \square$ Yes, positive point $(0 \sim 10)$; negative $\operatorname{point}(0 \sim 10)$

\section{Altruism}

$\square$ None( 0 point $) \square$ Yes, positive point $(0 \sim 10)$; negative $\operatorname{point}(0 \sim 10)$

VI Elements of physicians' professional image

1. de-professionalization

$\square$ None( 0 point $) \square$ Yes, positive point $(0 \sim 10)$; negative $\operatorname{point}(0 \sim 10)$

2. corporatization

$\square$ None $(0$ point $) \square$ Yes, positive point $(0 \sim 10)$; negative $\operatorname{point}(0 \sim 10)$

3. commercialization

$\square$ None( 0 point $) \square$ Yes, positive point( $0 \sim 10)$; negative $\operatorname{point}(0 \sim 10)$

\section{Directions}

$\square$ 1.Negative $\square$ 2.Neutral $\square$ 3.Positive

$\checkmark$ 4.Can’t identify because 
Appendix C. The coding criteria for data collected from Taiwan magazine

I Basic information of the articles
a. Reference number: (ex: Z88033101)
b. Staff:
c. Journal number:
d. Word count:
e. Physicians' photos on the paper? $\square 0$. No $\square 1$.Yes

II Types of articles

This part was set in order to identify the editorials of the journal.

\section{Sources}

a. Due to the variety of the sources of the magazine, the sources here were defined as individuals or organizations which provided materials for the writers.

b. Six categories were built for the reference of the researcher.

\section{Topics}

Topics of the articles meant the main points of the articles. It might be influenced by the magazine itself. 19 options were categorized for the reference of the researcher.

V Elements of physicians' image

1. Competence

$\square$ None $(0$ point $) \square$ Yes, positive point $(0 \sim 10)$; negative $\operatorname{point}(0 \sim 10)$

2. Autonomy

$\square$ None $(0$ point $) \square$ Yes, positive point $(0 \sim 10)$; negative $\operatorname{point}(0 \sim 10)$

3. Dominance

$\square$ None $(0$ point $) \square$ Yes, positive point $(0 \sim 10)$; negative $\operatorname{point}(0 \sim 10)$

4. Authority

$\square$ None $(0$ point $) \square$ Yes, positive point $(0 \sim 10)$; negative $\operatorname{point}(0 \sim 10)$

5. Altruism

$\square$ None $(0$ point $) \square$ Yes, positive point(0 10); negative $\operatorname{point}(0 \sim 10)$

VI Elements of physicians' professional image

1. de-professionalization

$\square$ None( 0 point $) \square$ Yes, positive point $(0 \sim 10)$; negative $\operatorname{point}(0 \sim 10)$

2. corporatization

$\square$ None( 0 point $) \square$ Yes, positive point $(0 \sim 10)$; negative $\operatorname{point}(0 \sim 10)$

3. commercialization

$\square$ None( 0 point $) \square$ Yes, positive point $(0 \sim 10)$; negative $\operatorname{point}(0 \sim 10)$

VII Directions

$\square$ 1.Negative $\square$ 2.Neutral $\square$ 3.Positive

$\square$ 4.Can’t identify because 